\title{
Periodic Revenue Fluctuation Among Listed Companies in Property and Real Estate Sub-Sector in Indonesia Stock Exchange
}

\author{
Jonnardi Jonnardi ${ }^{*}$, Nuryasman M. N. ${ }^{1}$ \\ ${ }^{1}$ Faculty of Economics and Business, Universitas Tarumanagara, Jakarta, Indonesia \\ *Corresponding author. Email: jonnardi@fe.untar.ac.id
}

\begin{abstract}
This research aimed to get an overview of the impact of the implementation of Indonesian Financial Accounting Standards (IFAS or PSAK in Indonesian) 72 which has been effective since January $1^{\text {st }}, 2020$ on financial performance and stock performance, especially among listed companies in the property and real estate sub-sector listed in the Indonesia Stock Exchange (IDX). The adoption of IFAS 72 has a direct impact on the amount of revenue reported in the calculation of profit or loss and comprehensive income on an annual or interim basis. The adoption of the new IFAS will fluctuate the calculation of annual and interim profit and loss and comprehensive income, thereby affecting the financial performance of listed companies which ultimately affects their stock performance in the capital market.

This research is a descriptive research to determine whether there are differences in financial performance and stock performance before and after the implementation of IFAS 72. The results of data analysis show that there are significant differences in financial performance, while for stock performance the differences are not significant.
\end{abstract}

Keywords: Financial performance, stock performance, revenue

\section{INTRODUCTION}

Indonesia began implementing the convergence of International Financial Reporting Standards (IFRS) against the Indonesian Financial Accounting Standards (IFAS) in 2008. This convergence was carried out gradually with the first target of implementing IFRS to be completed in 2012. The convergence of IFRS in Indonesia was effective starting from the year 2008 with the enactment of three new IAS-based IFAS. This was followed by one IAS-based IFAS which became effective in 2009. In 2010 there were three IFAS and one Financial Accounting Standard Interpretation (or FASI) based on IAS / IFRS and five IFAS revocation which were previously effective. Then in 2011, there were 15 IFAS and six IFRS-based FASI that were effective.

The convergence of IFRS is claimed to provide benefits for improving the quality of financial statements [1]. This has prompted studies to test empirically whether the application of IFRS convergence to Financial Accounting Standards has increased the ability of accounting information to estimate stock prices, or has value relevance [2].

The IFRS convergence which was carried out gradually against the Financial Accounting Standards resulted in revisions or even repeal of IFAS or FASI that had previously been in effect. The most recent IFRS convergence carried out by the Financial Accounting Standards Board (FASB) is by issuing three IFAS, namely IFAS 72 (adopted from IFRS 15) on Revenue from Contracts with Customers [3], IFAS 71 (adopted from IFRS 9) on Financial Instruments [4], and IFAS 73 (adopted from IFRS 16) about Leases [5]. All the three regulations were effective starting from January $1^{\text {st }}, 2020$.

The adoption of the new IFAS which has been effective since January $1^{\text {st }}, 2020$, which is principle based that must be applied to all companies in all different industries, will have different impacts for all companies listed in the Indonesia Stock Exchange (IDX). Characteristics of the industries in which listed companies conduct their business and the business transactions they carry out are factors that greatly influence the impact of the new IFAS on the company's financial statements. The adoption of IFAS 71 which replaces IFAS 55 [6], which uses expected loss in calculating the value of financial assets, will result in a significant increase in the allowance for impairment losses on financial assets [4]. Companies listed in the banking industry, especially the banking sub-sector and the financing sub-sector, will experience a significant impact on the company's operating income reporting.

The implementation of IFAS 72 replaces IFAS 23 (Income) [7], IFAS 34 (Construction Contracts) [8], IFAS 44 (Accounting for Real Estate Development Activities) [9], FASI 10 (Customer Loyalty Programs) [10], FASI 21 (Real Estate Construction Agreements) [11] and FASI 27 (Transfer of Assets from Customers) [12], whereas IFAS 72 states that the company recognizes revenue when (or as long as) the entity has fulfilled its performance obligations by transferring the promised goods or services (assets) to the customer. This provision will have a significant impact on listed companies 
in the Property, Real Estate, Construction and Telecommunications sectors. With IFAS 72, companies can no longer use the percentage of completion method in reporting periodic profit or loss.

The implementation of IFAS 73 replaces IFAS 30 (Leases) [13], FASI 8 (Transfer of Assets from Customers) [14], FASI 23 (Operating Leases-incentives) [15], FASI 24 (Evaluation of the Substance of Several Transactions that Include Legal Leases) [16] and FASI 25 (Land Rights), which regulates a company that has a lease contract containing a lease, the lessee will recognize the use rights assets and the lease liability [17]. This provision will result in the issuer, which has a lease contract from the owner of the asset (the lessee), will capitalize all lease payments as asset use rights and recognize lease obligations, as long as the lease contains the lease. The impact of the implementation of IFAS 73 will affect all listed companies in all industries, as long as they have rental contract transactions.

The research will be limited to studying the impact of the implementation of IFAS 72 "Revenue from Contracts with Consumers" especially on listed companies in the property and real estate sub-sector that develop High Rise Buildings that build hotels, shopping centers, condotels and apartments. The implementation of IFAS 72 which became effective in January 2020 will have a significant impact on periodic income reporting, where the implementation of IFAS 72 will result in fluctuating annual or interim income. During the construction period which takes 3 to 4 years until the handover of the unit to the customer, no revenue has been reported in the annual or interim calculation of profit or loss and comprehensive income, on the contrary, in the fourth year and the following year when the unit is completed, the company starts reporting revenue. This condition results in the implementation of IFAS 72 in industries with long-term revenue processes, which will result in the calculation of profit and loss and comprehensive income with a fluctuating profit or loss. During the construction period the profit will be small and even the loss and when the construction process is complete there will be an increase in reporting of income, even though substantially there has been no significant change in operational performance during the four-year period, except for the handover of the unit to the customer. The question that arises is whether the implementation of IFAS 72 does not distort the objectives of accounting reporting, so that it can mislead the economic decisions of users of financial statements.

\section{LITERATURE REVIEW AND HYPOTHESES}

The terminology of revenue in accounting is often something that is not easy to define because the revenue process of each industrial sector differs significantly, depending on the type of industrial sector. Companies engaged in the Trade and Services sector or the consumer goods sector will easily define their business income, but for companies engaged in the Agriculture, Animal Husbandry, Mining, Property, Real estate, Construction and other special industries sectors, defining revenue is not something that is easy.
The Indonesian Institute of Accountants defines revenue (IFAS 23) as the gross inflow of economic benefits arising from the normal activities of the company during a period when the cash inflows result in an increase in equity, which does not come from shareholder contributions [7]. Revenue, is measured at fair value, which is an amount, for which an asset may be exchanged or a liability settled between parties who understand and wish to conduct an arm's length transaction. This definition tends to regulate the timing and measurement of revenue, regardless of whether the recognized income is included in the definition of income. In order to get the right concept of revenue [19], it is necessary to separate about, a) the nature of revenue, b) measurement of revenue and c) timing of revenue.

\subsection{The Nature of Revenue}

There are two concepts for revenue [19]:

1. The concept of revenue which focuses on the inflow of assets as a result of the normal operation of the business (Inflow Concept)

2. The concept of revenue that focuses on creating goods and services and sending them to consumers, so this approach considers income as an outflow of good and services (Outflow Concept)

[20] added another concept:

3. The concept of revenue as a company product which emphasizes that income is the process of creating goods and services by the company (product concept).

[19] argued that the Product Concept is superior to the Outflow Concept, and the Outflow Concept is superior to the Inflow Concept. Furthermore, in determining the timing of revenue recognition and measurement of revenue, Product Concept is more neutral.

\subsection{The Timing of Revenue Recognition}

The accrual base for revenue recognition implies that revenue should be reported during production (in cases where profit can be calculated in proportion to the work done or services performed), at the end of production, at the time of product sale or at the time of collection of sales. Based on the accrual base which is also adopted in IFAS 23 (Revenue) [18], IFAS 34 (Construction Contracts) [8], and IFAS 44 (Accounting for Real Estate Development Activities) [9], it allows companies with long-term revenue processes such as Contractors, Developers who build High-Rise Buildings to recognize the revenue during the construction process. by using the percentage completion method, even though the product has not been submitted to the customer or the company's obligation to complete and deliver the product / implementation obligations have not been fully carried out.

\subsection{IFAS 72 is Effective Since January $1^{\text {st }}, 2020$}

Under IFAS 72, a company (entity) will recognize the revenue when (or as long as) the entity has fulfilled its performance 
obligations by transferring the promised goods or services (assets) to the customer and the customer has received a benefit from the asset being transferred [3]. The completion of the implementation obligations and receiving benefits by customers can be indicated by the following:

1) The entity has current rights to payment of assets

2) The customer has legal ownership rights over the asset.

3) The entity has transferred physical ownership of the asset.

4) The customer has significant risks and benefits of ownership of assets.

5) The customer has received from the use of the asset.

\subsection{Financial Performance and Company's Stock Performance}

Financial performance is a description of the company's performance in a certain period which can be seen from several main financial variables which include the variable of the company's ability to pay all its short-term liabilities (liquidity), the variable of the company's ability to get a return on the investment they use (Profitability), and the variable of capital structure which describes how a company funds the assets used in the business (leverage) [21]. All of the company's financial performance variables are the company's fundamental factors, ceteris paribus technical factors, are variables that are expected to affect the company's stock performance in the capital market or increase the company's value.

Stock performance that describes the stock return obtained by an investor, is basically a capital gain which is the difference between the resale price of shares and the acquisition price, after deducting transaction costs and final taxes on understanding transactions [22]. Stock returns can be in the form of realized returns and unrealized returns. Expected return on a stock portfolio is one of the factors that makes investors, especially short-term investors, invest or withdraw their funds in their investment portfolio [23].

In this study, the variable liquidity is proxied by the current ratio, the variable profitability is proxied by the return on investment, the variable capital structure is proxied by the debt to equity ratio and the variable stock performance is proxied by the stock return.

The implementation of the new IFAS in Indonesia will have a direct impact on financial performance and stock performance in several industrial sectors including the Property and Real Estate sub-sectors. One of the new standards to be implemented is IFAS 72 which regulates contract revenue from customers. Previously, the Property and Real sector in their periodic revenue recognition and measurement used IFAS 44 and FASI 21, but after the implementation of IFAS 72 , it will cause differences in the timing of recognition, measurement, presentation, and reporting of an entity's revenue.

The difference in standard is likely to have an impact on the financial performance of an entity which will ultimately affect the company's stock performance. This is because the revenue that is reported in the income statement and comprehensive income will later be related to other financial statements such as the Equity report, the statement of financial position, the cash flow statement to the disclosures in the notes to the financial statements.

$\mathrm{H}_{1}$ : There are differences in the financial performance of the property and real estate sub-sector companies after the implementation of IFAS 72.

$\mathrm{H}_{2}$ : There is a difference in the stock performance in the property and real estate sub-sector companies after the implementation of IFAS 72.

\section{RESEARCH METHOD}

This research is categoried as a quantitative research using descriptive research methods, to study the differences in financial performance and company stock performance before and after the implementation of IFAS 72. The research data were processed using SPSS statistical software, namely paired samples test to see the difference and significance of these differences in financial performance using three indicators, namely Profitability with the proxy of ROI, Liquidity with the proxy of the current ratio, capital structure with the proxy Debt-to-Equity Ratio / DER and stock performance by proxy with stock returns [24].

The population used is listed companies in the Construction Industry, property and real estate listed on the Indonesia Stock Exchange, especially property and real estate sub-sector companies that develop High Rise Buildings in the form of apartments, offices, condotels and shopping center developments. The total population of issuers in the property and real estate sub-sector is as many as 65 companies based on 2020 data, of which number developed the High-Rise Building which was used as a sample of 20 listed companies. The company that will be sampled is done by using a purposive sampling method with the following criteria:

1. Property and Real Estate Sub Sector Issuers listed on the IDX that have High Rise Buildings

2. Companies that have submitted their interim financial statements as of June 30, 2020.

3. Companies that have implemented IFAS 72 .

This study used secondary data, in form of interim financial reports published in IDX in the period prior to the implementation of IFAS 72, which are the interim financial reports as of 31 March 2019 and 30 June 2019 as well as the interim reports post IFAS 72 implementations, which are the reports as of 31 March 2020 and 30 June 2020, along with stock price development during those periods.

\section{RESULTS AND DISCUSSION}

\subsection{Financial Performance}

Theoretically we can expect changes in reporting revenue in the calculation of profit and loss and comprehensive income (Profit-Loss) due to the implementation of IFAS 72 in the property and real estate sub-sector, especially the High-Rise Building, will have a negative impact on the company's financial performance assessment, and further will affect the 
performance of the company's shares on the stock exchange. In general, in industries where the process of revenue to delivery of products or services sold does not require a long time, the implementation of IFAS 72 does not have a significant effect on financial performance reporting or company stock performance for the current year. The implementation of IFAS 72 in the property and real estate subsector, particularly the High-rise building, will result in fluctuating annual or interim financial and stock performance. During the construction process, no revenue was reported, when construction was completed and when the handover began, the unit revenue was reported to have increased sharply from the previous year. The following is based on the results of research data processing and paired samples test, a description of the financial performance and performance of the company's shares as follows:

\subsection{Profitability}

The calculation of the difference in profitability in Table 1, the output results from Paired Sample Statistics show that there are differences in the profitability of companies before the implementation of IFAS 72 with after the application. The profitability of the company prior to the implementation of IFAS 72 where revenue recognition is recognized periodically based on the estimated level of project completion in the period, for customers who pay advances above $20 \%$, the company's profitability level is $1.66 \%$ for an interim period of three months, whereas after the implementation of IFAS 72 where revenue can only be recognized after the project is completed and handed over, the profitability for the same interim period drops to - $.002 \%$ (negative). This condition substantively occurs not because of a decrease in operational performance of management, but because of a change in the accounting principles used by the company in recognizing its revenue. Statistically, this decline in performance will be interpreted as a decrease in real performance, such as construction progress that is not on schedule, company products that are not absorbed by the market, lack of liquidity and so on. The substance is not like this, IFAS 72 delays revenue recognition until it is $100 \%$ progress and the unit is handed over to customers. For short-term investors, fluctuations in annual or interim earnings will be interpreted as a change in investment risk which prompts them to relinquish what they own, which in general will reduce the share price of the listed company.

Table 1 Paired-Sample Statistics

\begin{tabular}{|ll|r|c|c|c|}
\hline & & \multicolumn{1}{|c|}{ Mean } & $\mathrm{N}$ & Std. Deviation & Std. Error Mean \\
\hline \multirow{2}{*}{ Pair 1 } & Before &, 01662 & 40 &, 026271 &, 004154 \\
& After &,- 00002 & 40 &, 020765 &, 003283 \\
\hline
\end{tabular}

The calculation of how strong the correlation of profitability before the implementation of IFAS 72 with profitability after implementation is shown in Table 2, showing the correlation value based on the output of Paired Sample Correlations of $39.4 \%$ with a significant value of 0.012 . The correlation value can be interpreted that the correlation of profitability after the implementation of IFAS 72 and before the implementation is categorized as weak and significant. Theoretically, the correlation between the implementation of IFAS 72 should be very strong or strong. This weak correlation value can be explained because the financial statements used are consolidated financial statements, where the contribution of revenue from the sale of high-rise building in the overall $/$ consolidated income on average is carried $50 \%$. The rest is income from the sale of land, landed houses and environmental management.

Table 2 Paired-Sample Correlation

\begin{tabular}{|l|c|c|c|}
\hline & N & Correlation & Sig. \\
\hline Pair 1 Before \& After & 40 &, 394 &, 012 \\
\hline
\end{tabular}

Different tests conducted to determine the significance, differences in profitability before and after the implementation of IFAS 72 can be seen in Table 3, the results of the Paired Sample Test show that there is a difference in average profitability / paired differences mean amounting of $1.66 \%$ and the difference is significant, where the value is significant. at the level of $\alpha 5 \%$, which means that the research hypothesis can be accepted. The implementation of IFAS 72, which was effective on January $1^{\text {st }}, 2020$, has proven to have an impact on causing a difference to business profitability.

Table 3 Paired-Sample Test

\begin{tabular}{|c|c|c|c|}
\hline & & & Pair 1 \\
\hline & & & Befor - After \\
\hline Paired Differences & Mean & &, 016632 \\
\hline & Std. Deviation & & ,026297 \\
\hline & Std. Error Mean & & ,004158 \\
\hline & $95 \%$ Confidence Interval of & Lower & ,008222 \\
\hline & the Difference & Upper &, 025042 \\
\hline
\end{tabular}




\begin{tabular}{|l|r|}
$\mathrm{T}$ & 4,000 \\
$\mathrm{Df}$ & 39 \\
Sig. (2-tailed) &, 000 \\
\hline
\end{tabular}

Source: Data processed by using SPSS 2020

\subsection{Liquidity}

Calculation of liquidity differences in table 4, the results of Paired Sample Statistics show that there are differences in company liquidity before the implementation of IFAS 72 and after the application. The company's liquidity before the implementation of IFAS 72 was 2.265 times for the interim period of three months, while after the implementation of IFAS 72 for the same interim period it decreased to 2.022 times. The difference in liquidity is statistically due to the implementation of IFAS 72, the substance of changes in liquidity is not directly related to revenue recognition, cash inflows in this industry are obtained from advances and payment of invoices. The decline in liquidity was statistically due to the implementation of IFAS 72, the substance of this decline could be due to a decrease in demand for apartment units or offices that were sold due to the absence of a solution to the pandemic convid 19 and the unfavorable economic conditions in Indonesia.

Table 4 Paired-Sampled Statistics

\begin{tabular}{|ll|c|c|c|c|}
\hline & Mean & N & Std. Deviation & Std. Error Mean \\
\hline Pair 1 & Before & 2,26520 & 40 & 1,835020 &, 290142 \\
& After & 2,02241 & 40 & 1,411945 &, 223248 \\
\hline
\end{tabular}

The calculation of how strong the correlation of liquidity before the implementation of IFAS 72 with liquidity after application in Table 5 shows the results of the correlation test between liquidity before and after the implementation of IFAS 72 based on the results of Paired Sample Correlations, it is known that the correlation coefficient value is $88 \%$ with a significant value of 0.00 . The correlation value can be interpreted that the correlation of liquidity after the implementation of IFAS 72 and before the application is categorized as strong and significant. The decrease in the number of apartment units or offices sold as a result of the convid 19 pandemic and the unfavorable economic conditions in Indonesia could also be a variable that causes a decrease in liquidity.

Table 5 Paired-Sampled Correlation

\begin{tabular}{|l|c|c|c|}
\hline & $\mathrm{N}$ & Correlation & Sig. \\
\hline Pair 1 Before \& After & 40 &, 880 &, 000 \\
\hline
\end{tabular}

Different tests conducted to determine the significance, differences in liquidity before and after the implementation of IFAS 72 can be seen in table 6, the results of the Paired Sample Test show that there is a difference in mean liquidity / paired differences mean amounting of 0.242 times and the difference is not significant at $\alpha 5 \%$ level and significant at $\alpha 10 \%$. At the level of $\alpha 10 \%$, it means that the research hypothesis can be accepted. The implementation of IFAS 72, which became effective on January 1, 2020, has proven to have an impact on causing differences in business liquidity.

Table 6 Paired-Sample Test

\begin{tabular}{|c|c|c|c|}
\hline & & & Pair 1 \\
\hline & & & Before - After \\
\hline Paired Differences & Mean & & ,242785 \\
\hline & Std. Deviation & & ,894174 \\
\hline & Std. Error Mean & &, 141381 \\
\hline & $95 \%$ Confidence Interval of & Lower &,- 043186 \\
\hline & the Difference & Upper & ,528756 \\
\hline $\mathrm{T}$ & & & 1,717 \\
\hline & & & 39 \\
\hline Sig. (2-tailed) & & & ,094 \\
\hline
\end{tabular}

Source: Data processed by using SPSS 2020

\subsection{Capital Structure}

The results of processing capital structure data in Table 7, the results of Paired Sample Statistics show differences in the capital structure of companies before the implementation of IFAS 72 and after the implementation. The company's capital 
structure prior to the implementation of IFAS 72 was $90.71 \%$ for an interim period of three months, while after the implementation of PASK 72 for the same interim period it increased to $98.59 \%$. The increase in capital structure can be explained statistically, with a decrease in the amount of income recognized by the application of IFAS 72, it will have an impact on the decrease in internal sources of capital, which ultimately reduces the company's equity.

A decrease in equity will ultimately increase the composition of debt in the company's capital structure. The substance of the increase in capital structure is more due to, during the Covid 19 pandemic, and the occurrence of national economic contraction in the second quarter of 2020, companies in this sub-sector, were most affected by a large decline in demand, which ultimately could no longer afford to pay their obligations to creditors (principal and interest), all companies in this sub-sector ask for a restructuring of their debt, in the form of delaying principal payments, and lowering loan interest.

Table 7 Paired-Sample Statistics

\begin{tabular}{|ll|c|c|c|c|}
\hline & & Mean & N & Std. Deviation & Std. Error Mean \\
\hline Pair 1 & Before &, 90712 & 40 &, 562311 &, 088909 \\
& After &, 98596 & 40 &, 708203 &, 111977 \\
\hline
\end{tabular}

The results of data processing in table 8 show the results of the correlation test between the two data, namely the capital structure before and after the implementation of IFAS 72 Based on the results of the Paired Sample Correlations, it is known that the correlation coefficient value is $62.3 \%$ with a significant value of 0.00 . Because the significant value is smaller than 0.05 , it can be said that statistically there is a strong correlation between the value of the capital structure before and after the implementation of IFAS 72 .

Table 8 Paired-Sample Correlation

\begin{tabular}{|ll|c|c|c|}
\hline & N & Correlation & Sig. \\
\hline Pair 1 & Before \& After & 40 &, 623 &, 000 \\
\hline
\end{tabular}

The results of data processing in table 9, the output results from the Paired Sample Test show that there is a difference in the mean capital structure of $-7.8 \%$ and from the results of different tests, the difference is not significant at the $\alpha$ level of $5 \%$, this means statistically the research hypothesis cannot be accepted. The implementation of PASK 72, which was effective on January 1, 2020, proved to have made no difference to the company's capital structure. From table 9, it can be seen that the standard deviation is 0.567 with a mean
-0.0788 , this means that the standard deviation is relatively large, namely 7.27 times the mean. The amount of standard deviation can mean that the difference in capital structure before and after implementation (paired differences in mean) between companies sampled is quite large, so that this condition will have an impact when a different test is performed, it is statistically insignificant, in fact the application of IFAS 72 causes differences in each company.

Table 9 Paired-Sample Test

\begin{tabular}{|c|c|c|c|}
\hline & & & Pair 1 \\
\hline & & & Before - After \\
\hline Paired Differences & Mean & &,- 078833 \\
\hline & Std. Deviation & & ,567233 \\
\hline & Std. Error Mean & & ,089687 \\
\hline & $95 \%$ Confidence Interval of & Lower &,- 260243 \\
\hline & the Difference & Upper & , 102577 \\
\hline $\mathrm{t}$ & & &,- 879 \\
\hline & & & 39 \\
\hline Sig. (2-tailed) & & & ,385 \\
\hline
\end{tabular}

Source: Data Processed by using SPSS 2020

\subsection{Company Stock Performance}

The results of processing stock performance data in Table 10, the output results from Paired Sample Statistics show differences in the performance of the company's stock before the implementation of IFAS 72 with after the application. The company's stock performance before the implementation of
IFAS 72 was $5.73 \%$ for an interim period of three months, while after the implementation of IFAS 72 for the same interim period it decreased to $-1.621 \%$. The decline in stock performance can be explained by the decrease in the amount of revenue recognized by the implementation of IFAS 72, which will give a negative signal to the company's performance, which in turn will have an impact on the decline 
in the company's stock price on the stock exchange. The decline in prices could also be due to the pandemic convid 19 which had not been resolved until the second quarter of 2020 and the unfavorable condition of the Indonesian economy. The
Indonesian economy in the second quarter of 2020 contracted by $5.32 \%$ yoy and twice compared to Q to Q with the first quarter of 2020 economic growth of $-4.19 \%$ (Head of BPS, Suhariyanto).

Table 10 Paired-Sample Statistics

\begin{tabular}{|ll|c|c|c|c|}
\hline & & Mean & $\mathrm{N}$ & Std. Deviation & Std. Error Mean \\
\hline Pair 1 & Before &, 05734 & 40 &, 232835 &, 036814 \\
& After &,- 01621 & 40 &, 960120 &, 151808 \\
\hline
\end{tabular}

The data processing in table 11 shows the results of the correlation test between the two data, namely the stock performance before and after the implementation of IFAS 72. Based on the results of the Paired Sample Correlations, it is known that the correlation coefficient value is $-5.2 \%$ with a significant value of 0.752 . Because the significant value is greater than 0.05 , it can be said that there is no relationship between the value of stock performance before and after the implementation of IFAS 72. This can be explained that macroeconomic factors and conditions in Indonesia in general / the COVID-19 pandemic have had a major impact on the decline in the performance of listed companies' shares on the capital market.

Table 11 Paired-Sample Correlation

\begin{tabular}{|ll|c|c|c|}
\hline & $\mathrm{N}$ & Correlation & Sig. \\
\hline Pair 1 & Before \& Afer & 40 &,- 052 &, 752 \\
\hline
\end{tabular}

The results of data processing in table 12, the output results from the Paired Sample Test show that there is a difference in the performance of the paired differences in the mean of $7.35 \%$ and the difference is not significant at the $\alpha 5 \%$ level, statistically this means that the research hypothesis cannot be accepted. The implementation of PASK 72 is proven to have made no difference to the company's stock performance. From table 12 Paired difference mean before and after is 0.0735 with a relatively high standard deviation of 0.999 , amounting to
13.5 times the mean. The amount of standard deviation can mean that the difference in the performance of capital stocks before and after the implementation (paired differences mean) between the companies sampled is quite large, so that these conditions will have an impact when the difference test is carried out, it becomes statistically insignificant, in fact the application of IFAS 72 causes differences in performance shares of every company.

Table 12 Paired-Sample Test

\begin{tabular}{|c|c|c|c|}
\hline & & & Pair 1 \\
\hline & & & Before - After \\
\hline Paired Differences & Mean & &, 073543 \\
\hline & Std. Deviation & & ,999567 \\
\hline & Std. Error Mean & &, 158045 \\
\hline & $95 \%$ Confidence Interval of & Lower &,- 246134 \\
\hline & the Difference & Upper & ,393220 \\
\hline $\mathrm{T}$ & & & ,465 \\
\hline & & & 39 \\
\hline Sig. (2-tailed) & & & 644 \\
\hline
\end{tabular}

Source: Data Processed by using SPSS 2020

\section{CONCLUSIONS AND IMPLICATIONS}

Based on the research hypothesis formulated previously, it is evident from the results of data processing, for financial performance variables with profitability, liquidity and capital structure as indicators, it turns out that there are differences between profitability, liquidity and capital structure before and after the implementation of IFAS 72. From the results of the paired-sample test, the profitability variable is significant at the $\alpha 5 \%$ level, the liquidity variable is not significant at the $\alpha$
$5 \%$ level, but is significant at the $\alpha 10 \%$ level and the capital structure variable is not significant at the $\alpha 5 \%$ or $10 \%$ level. For the stock performance variable, there is a relatively large difference in performance, but not significant at the $\alpha$ level of $5 \%$ or $10 \%$.

The implications of this research can be helpful for listed companies, especially the property and real estate sub-sector, proposing to the IAI Financial Accounting Standards Board (FASB) to postpone the implementation of IFAS 72 for the next two or three years, so that they can prepare a business model in accordance with the needs of IFAS 72 . it is 
impossible to implement IFAS 72, the solution that must be done by listed companies in this sub-sector is to ensure that the delivery of high-rise building units is carried out partially or all the time, without having to wait for the construction process of all units to be completely finished.

In a disruptive era whereas business innovation is a necessity with the increasingly sophisticated IT development, it will encourage existing companies to transform their business models, or be defeated by innovative newcomers, with a business model that fits the era. The future IFRS convergence is principle based, which will encourage research to test empirically whether the application of IFRS convergence to Financial Accounting Standards in the future will still improve the quality of financial reporting of old companies, instead distorting the reporting itself.

\section{REFERENCES}

[1] Barth, M. E. 2008. Global Financing Reporting: Implication for US Academics. The Accounting Review, 83, 1159-1179.

[2] Kargin, S. 2013. The Impact of IFRS on The Value Relevance of Accounting Information: Evidence from Turkish Firms. International Journal of Economics and Finance, 5, 71-80.

[3] Ikatan Akuntan Indonesia, PSAK 72: Pendapatan dari Kontrak dengan Pelanggan. Jakarta: Ikatan Akuntan Indonesia, 2017.

[4] Ikatan Akuntan Indonesia, PSAK 71: Instrumen Keuangan. Jakarta: Ikatan Akuntan Indonesia, 2017.

[5] Ikatan Akuntan Indonesia, PSAK 73: Sewa. Jakarta: Ikatan Akuntan Indonesia, 2017.

[6] Ikatan Akuntan Indonesia, PSAK 55: Instrumen Keuangan: Pengakuan dan Pengukuran. Jakarta: Ikatan Akuntan Indonesia, 2014.

[7] Ikatan Akuntan Indonesia, PSAK 23: Pendapatan. Jakarta: Ikatan Akuntan Indonesia, 2010.

[8] Ikatan Akuntan Indonesia, PSAK 34: Kontrak Konstruksi. Jakarta: Ikatan Akuntan Indonesia, 2010.

[9] Ikatan Akuntan Indonesia, PSAK 44: Akuntansi Aktivitas Pengembang Real Estat. Jakarta: Ikatan Akuntan Indonesia, 1997.

[10] Ikatan Akuntan Indonesia, ISAK 10: Program Loyalitas Pelanggan. Jakarta: Ikatan Akuntan Indonesia, 2014.
[11] Ikatan Akuntan Indonesia, ISAK 21: Perjanjian Konstruksi Real Estat. Jakarta: Ikatan Akuntan Indonesia, 2012.

[12] Ikatan Akuntan Indonesia, ISAK 27: Pengalihan Aset dari Pelanggan. Jakarta: Ikatan Akuntan Indonesia, 2013.

[13] Ikatan Akuntan Indonesia, ISAK 30: Sewa. Jakarta: Ikatan Akuntan Indonesia, 2011.

[14] Ikatan Akuntan Indonesia, ISAK 8: Perjanjjian yang Mengandung Sewa. Jakarta: Ikatan Akuntan Indonesia, 2014.

[15] Ikatan Akuntan Indonesia, ISAK 23: Perjanjjian yang Mengandung Sewa. Jakarta: Ikatan Akuntan Indonesia, 2012.

[16] Ikatan Akuntan Indonesia, ISAK 24: Evaluasi Substansi Beberapa Transaksi yang Melibatkan Suatu Bentuk Legal Sewa. Jakarta: Ikatan Akuntan Indonesia, 2012.

[17] Ikatan Akuntan Indonesia, ISAK 25: Hak atas Tanah. Jakarta: Ikatan Akuntan Indonesia, 2011

[18] Ikatan Akuntan Indonesia, PSAK 23: Pendapatan. Jakarta: Ikatan Akuntan Indonesia, 2010.

[19] Hendriksen, E. S. and M. Van Breda. 2002. "Teori Akuntansi”, Edisi Kelima. Batam: Interaksara.

[20] Paton, W. A. 1922. Accounting Theory with Special Reference to the Corporate Enterprise. New York, NY: The Ronald Press Company.

[21] Kasmir, 2015. Analisis Laporan Keuangan, Edisi ke3, Jakarta: PT Rajagrafindo.

[22] Arista, Desy; dan Astohar. 2012. Analisis Faktor Faktor yang Mempengaruhi Return Saham (Studi Kasus pada Perusahaan Manufaktur yang Go Public di BEI Periode Tahun 2005-2009). Jurnal Ilmu Manajemen dan Akuntansi Terapan, Vol. 3, No.1.

[23] Eduardus Tandelilin, 2010. Portofolio dan Investasi, Edisi Pertama. Yogyakarta: Universitas Gajah Mada.

[24] Sunarjanto, Agus. 2007. Analisis Kinerja Keuangan Perusahaan Sebelum dan Sesudah Seasoned Equity Offering di Bursa Efek Jakarta. Jurnal Organisasi dan Manajemen, Vol. 3. 